\title{
PENDIDIKAN ISLAM DAN MODERNITAS
}

\section{Oleh :}

\author{
Suryono*
}

\section{ABSTRAK}

Pendidikan merupakan proses budaya untuk meningkatkan harkat dan martabat manusia yang berlangsung sepanjang hayat. Pendidikan selalu berkembang, dan selalu dihadapkan pada perubahan zaman. Untuk itu, mau tak mau pendidikan harus didisain mengikuti irama perubahan tersebut, apabila pendidikan tidak didisain mengikuti irama perubahan, maka pendidikan akan ketinggalan dengan lajunya perkembangan zaman itu sendiri. Siklus perubahan pendidikan pada diagram di atas, dapat dijelaskan sebagai berikut; Pendidikan dari masyarakat, didisain mengikuti irama perubahan dan kebutuhan masyarakat.

Untuk itu, dalam pelaksanaannya, pendidikan Islam harus memperhatikan hal-hal sebagai beriku; (1) Dalam menghadapi perubahan masyarakat modern, secara internal pendidikan Islam harus menyelesaikan persoalan dikotomi, tujuan dan fungsi lembaga pendidikan Islam, dan persolalan kurikulum atau materi yang sampai sekarang ini belum terselesaikan. (2) Lembaga- lembaga pendidikan Islam perlu mendisain ulang fungsi pendidikan, dengan memilih model pendidikan yang relevan dengan perubahan zaman dan kebutuhan masyarakat. (3) Pendidikan Islam didisain untuk dapat membantu meningkatkan ketrampilan dan pengetahuan untuk bekerja lebih produktif sehingga dapat meningkatan kerja lulusan pendidikan di masa datang. (4) Pendidikan Islam harus mengembangkan kualitas pendidikannya agar memenuhi kebutuhankebutuhan masyarakat yang selalu berubah-berubah.Lembagalembaga pendidikan Islami harus dapat menyiapkan sumber insani yang lebih handal dan memiliki kompotensi untuk hidup bersama dalam ikatan masyarakat modern.

Kata Kunci : Pendidikan Islam, Modernitas

\section{Pendahuluan}

Pendidikan Islam, suatu pendidikan yang melatih perasaan murid-

\section{* IAIT Kediri.}


murid dengan cara begitu rupa sehingga dalam sikap hidup, tindakan, keputusan, dan pendekatan mereka terhadap segala jenis pengetahuan, mereka dipengaruhi sekali oleh nilai spritual dan sangat sadar akan nilai etis Islam, ${ }^{1}$ atau "Pendidikan Islam mengantarkan manusia pada perilaku dan perbuatan manusia yang berpedoman pada syariat Allah ${ }^{2}$ Pendidikan Islam bukan sekedar "transfer of knowledge" ataupun "transfer of training", ....tetapi lebih merupakan suatu sistem yang ditata di atas pondasi keimanandan kesalehan; suatu sistem yang terkait secara langsung dengan Tuhan. ${ }^{3}$ Pendidikan Islam suatu kegiatan yang mengarahkan dengan sengaja perkembangan seseorang sesuai atau sejalan dengan nilai-nilai Islam.

Dari pengertian di atas, pendidikan merupakan sistem untuk meningkatkan kualitas hidup manusia dalam segala aspek kehidupan. Dalam sejarah umat manusia, hampir tidak ada kelompok manusia yang tidak menggunakan pendidikan sebagai alat pembudayaan dan peningkatan kualitasnya. Pendidikan dibutuhkan untuk menyiapkan anak manusia demi menunjang perannya di masa datang. Upaya pendidikan yang dilakukan oleh suatu bangsa memiliki hubungan yang signifikan dengan rekayasa bangsa tersebut di masa mendatang. Dengan demikian, pendidikan merupakan sarana terbaik untuk menciptakan suatu generasi baru pemuda-pemudi yang tidak akan kehilangan ikatan dengan tradisi mereka sendiri tapi juga sekaligus tidak menjadi bodoh secara intelektual atau terbelakang dalam pendidikan mereka atau tidak menyadari adanya perkembangan-perkembangan disetiap cabang pengetahuan manusia.

Pendidikan merupakan proses budaya untuk meningkatkan harkat dan martabat manusia yang berlangsung sepanjang hayat. Pendidikan selalu berkembang, dan selalu dihadapkan pada perubahan zaman. Untuk itu, mau tak mau pendidikan harus didisain mengikuti irama perubahan tersebut, apabila pendidikan tidak didisain mengikuti irama perubahan, maka pendidikan akan ketinggalan dengan lajunya perkembangan zaman itu sendiri. Siklus perubahan pendidikan pada diagram di atas, dapat dijelaskan

${ }^{1}$ Syed Sajjad Husaian dan Syed Ali Ashraf, Crisis Muslim Educatio"., Terj. Rahmani Astuti, Krisis Pendidikan Islam, Risalah, Bandung, 1986. 2.

2 Abdurrahman an-Nahlawi, Ushulut Tarbiyah Islamiyah wa Asalabih fi Baiti wa Madrasati wal Mujtama', Dar al-Fikr al-Mu'asyr, Beirut-Libanon., Terj. Shihabuddin, Pendidikan Islam di Rumah Sekolah dan Masyarakat, Gema Insani Press, Jakarta, 1995. 26.

${ }^{3}$ Ibid. 
sebagai berikut; Pendidikan dari masyarakat, didisain mengikuti irama perubahan dan kebutuhan masyarakat. Misalnya; pada peradaban masyarakat agraris, pendidikan didisain relevan dengan irama perkembangan peradaban masyarakat agraris dan kebutuhan masyarakat pada era tersebut. Begitu juga pada peradaban masyarakat industrial dan informasi, pendidikan didisain mengikuti irama perubahan dan kebutuhan masyarakat pada era industri dan informasi, dan seterusnya. Demikian siklus perkembangan perubahan pendidikan, kalau tidak pendidikan akan ketinggalan dari perubahan zaman yang begitu cepat. Untuk itu perubahan pendidikan harus relevan dengan perubahan zaman dan kebutuhan masyarakat pada era tersebut, baik pada konsep, materi dan kurikulum, proses, fungsi serta tujuan lembaga-lembaga pendidikan.

Pendidikan Islam sekarang ini dihadapkan pada tantangan kehidupan manusia modern. Dengan demikian, pendidikan Islam harus diarahkan pada kebutuhan,perubahan masyarakat modern. Dalam menghadapi suatu perubahan, "diperlukan suatu,disain paradigma baru di dalam menghadapi tuntutan-tuntutan yang baru, demikian kata filsuf Kuhn. Menurut Kuhn, apabila tantangan-tantangan baru tersebut dihadapi dengan menggunakan paradigma lama, maka segala usaha yang dijalankan akan memenuhi kegagalan". ${ }^{4}$ Untuk itu, pendidikan Islam perlu didisain untuk menjawab tantangan prubahan zaman tersebut, baik pada sisi konsepnya, kurikulum, kualitas sumberdaya insaninya, lembaga-lembaga dan organisasinya, serta mengkonstruksinya agar dapat relevan dengan perubahan masyarakat tersebut.

\section{Karakteristik Masyarakat Modern}

Pendapat Alvin Tofler dalam bukunya The Third Wave (1980) yang bercerita tentang peradaban manusia, yaitu; (1) perdaban yang dibawa oleh penemuan pertanian, (2) peradaban yang diciptakan dan dikembangkan oleh revolusi industri, dan (3) peradaban baru yang tengah digerakan oleh revolusi komunikasi dan informasi. Perubahan tersebesar yang diakibatkan oleh gelombang ketiga adalah, terjadinya pergeseran yang mendasar dalam sikap dan tingkah laku masyarakat. ${ }^{5}$ Salah satu ciri utama kehidupan di masa

${ }^{4}$ H.A.R. Tilar, Beberapa Agenda Reformasi Pendidikan Nasional Dalam Perspektif Abad 21, Tera Indonesia, Magelang, Cet. I, 1998. 245.

5 M.Irsyad Sudiro, Pendidikan Agama dalam Masyarakat Modern, Seminar dan Lokakarya Nasional Revitalisasi Pendidikan Agama Luar Sekolah dalam Masyarakat 
sekarang dan masa yang akan datang adalah cepatnya terjadi perubahan yang terjadi dalam kehidupan manusia.

Banyak paradigma yang digunakan untuk menata kehidupan, baik kehidupan individual maupun kehidupan organisasi yang pada waktu yang lalu sudah mapan, kini menjadi ketinggalan zaman. ${ }^{6}$ Secara umum masyakarat modern adalah masyarakat yang proaktif, individual, dan kompetitif. Masyarakat modern dewasa ini yang ditandai dengan munculnya pasca industri (postindustrial society) seprti dikatakan Daniel Bell, atau masyarakat informasi (information society) sebagai tahapan ketiga dari perkembangan perdaban seperti dikatakan oleh Alvin Tofler, tak pelak lagi telah menjadikan kehidupan manusia secara teknologis memperoleh banyak kemudahan. Tetapi juga masyarakat modern menjumpai banyak paradoks dalam kehidupannya. Dalam bidang revolusi informasi, sebagaimana dikemukakan Donald Michael, juga terjadi ironi besara. Semakin banyak informasi dan semakin banyak pengetahuan mestinya makin besara kemampuan melakukan pengendalian umum. Tetapi yang terjadi justru sebaliknya, semakin banyak informasi telah menyebabkan semakin disadari bahwa segala sesuatunya tidak terkendali. Di masyarakat Barat, ia telah menimbulkan sejumlah besar persoalan, yang tidak ada pemecahannya kecuali cara pemecahan yang tumpul. Di lingkungan masyarakat kita sendiri misalnya, telah terjadi swastanisasi televisi, masyarakat mulai merasakan ekses negatifnya.

Keprihatinan Toynbee melihat perkembangan peradaban modern yang semakin kehilangan jangkar spritual dengan segala dampak destruktifnya pada berbagai dimensi kehidupan manusia. Manusia modern ibarat layang-layang putus tali, tidak mengenal secara pasti di mana tempat hinggap yang seharusnya. Teknologi yang tanpa kendali moral lebih merupakan ancaman. Dan "ancaman terhadap kehidupan sekarang" tulis Erich Fromm, "bukanlah ancaraman terhadap satu kelas, satu bangsa, tetapi merupakan ancaman terhadap semua". ${ }^{7}$ Menurut A. Syafi'i Ma'arif, bahwa sistem pendidikan tinggi modern yang kini berkembang di seluruh dunia

\footnotetext{
Modern, Cirebon, tanggal, 30-31 Agusrus 1995. 2.

${ }^{6}$ Djamaluddin Ancok, Membangun Kompotensi Manusia dalam Milenium Ke Tiga, Psikologika, Jurnal Pemikiran dan Penelitian Psikologi, Nomor : 6 Tahun III, UII, 1998. 5.

${ }^{7}$ Erich Fromm, The Revolution of Hope : Toward a Humanized Technology, New York : Harper \& Raw, 1968, p. 5.,dalam Syafi'i Ma'arif, Pengembangan Pendidikan Tinggi Post Graduate Studi Islam Melalui Paradigma Baru Yang Lebih Efektif, 1997. 7.
} 
lebih merupakan pabrik doktor yang kemudian menjadi tukang-tukang tingkat tinggi, bukan melahirkan homo sapiens. Bangsa-bangsa Muslim pun terjebak dan terpasung dalam arus sekuler ini dalam penyelenggaraan pendidikan tingginya. Kita belum mampu menampilkan corak pendidikan alternatif terhadap arus besar high learning yang dominan dalam peradaban sekuler sekarang ini. Prinsip ekonomi yang menjadikan pasar sebagai agama baru masih sedang berada di atas angin. Manusia modern sangat tunduk kepada agama baru ini. ${ }^{8}$

Dampak dari semua kemajuan masyarakat modern, kini dirasakan demikian fundamental sifatnya. Ini dapat ditemui dari beberapa konsep yang diajukan oleh kalangan agamawan, ahli filsafat dan ilmuan sosial untuk menjelaskan persoalan yang dialami oleh masyarakat. Misalnya, konsep keterasingan (alienation) dari Marx dan Erich Fromm, dan konsep anomie dari Durkheim. Baik alienation maupun anomie mengacu kepada suatu keadaan dimana manusia secara personal sudah kehilangan keseimbangan diri dan ketidakberdayaan eksistensial akibat dari benturan struktural yang diciptakan sendiri. Dalam keadaan seperti ini, manusia tidak lagi merasakan dirinya sebagai pembawa aktif dari kekuatan dan kekayaannya, tetapi sebagai benda yang dimiskinkan, tergantung kepada kekuatan di luar dirinya, kepada siapa ia telah memproyeksikan substansi hayati dirinya.

Semua persoalan fundamental yang dihadapi oleh masyarakat modern yang digambarkan di atas, "menjadi pemicu munculnya kesadaran epistemologis baru bahwa persoalan kemanusian tidak cukup diselesaikan dengan cara empirik rasional, tetapi perlu jawaban yang bersifat transendental". Melihat persoalam ini, maka ada peluang bagi pendidikan Islam yang memiliki kandungan spritual keagamaan untuk menjawab tantangan perubahan tersebut. Fritjop Capra dalam buku The Turning Point, "mengajak untuk meninggalkan paradigma keilmuan yang terlalu materialistik dengan mengenyampingkan aspek spritual keagamaan. Demikianlah, agama pada akhirnya dipandang sebagai alternatif paradigma yang dapat memberikan solusi secara mendasar terhadap persoalan kemanusian yang sedang dihadapi oleh masyarakat modern". ${ }^{9}$

Mencermati fenomena peradaban modern yang dikemukakan di atas,

${ }^{8}$ Ahmad Syafi'i Ma'arif, Pemikiran tentang Pembaharuan Pendidikan Islam di Indonesia, Dalam Pendidikan Islam di Indonesia antara Cita dan Fakta, Editor : Muslih Usa, Tiara Wacana, Yogyakarta, 1991. 7.

${ }^{9}$ Ibid. 
harus bersikap arif dalam merespons fenomena-fenomena tersebut. Dalam arti, jangan melihat peradaban modern dari sisi unsur negatifnya saja, tetapi perlu juga merespons unsur-unsur posetifnya yang banyak memberikan manfaat dan mempengaruhi kehidupan manusia. Maka, yang perlu diatur adalah produk peradaban modern jangan sampai memperbudah manusia atau manusia menghambakan produk tersebut, tetapi manusia harus menjadi tuan, mengatur, dan memanfaatkan produk perabadaban modern tersebut secara maksimal.

\section{Pendidikan Tradisional dan Modern}

Pendidikan tradisional (konsep lama) sangat menekankan pentingnya penguasaan bahan pelajaran. Menurut konsep ini rasio ingatanlah yang memegang peranan penting dalam proses belajar di sekolah. ${ }^{10}$ Pendidikan tradisional telah menjadi sistem yang dominan di tingkat pendidikan dasar dan menengah sejak paruh kedua abak ke-19, dan mewakili puncak pencarian elektik atas 'satu sistem terbaik'. Ciri utama pendidikan tradisional termasuk : (1) anak-anak biasanya dikirim ke sekolah di dalam wilayah geografis distrik tertentu, (2) mereka kemudian dimasukkan ke kelas-kelas yang biasanya dibeda-bedakan berdasarkan umur, (3) anak-anak masuk sekolah di tiap tingkat menurut berapa usia mereka pada waktu itu, (4) mereka naik kelas setiap habis satu tahun ajaran, (5) prinsip sekolah otoritarian, anak-anak diharap menyesuaikan diri dengan tolok ukur perilaku yang sudah ada, (6) guru memikul tanggung jawab pengajaran, berpegang pada kurikulum yang sudah ditetapkan, (7) sebagian besar pelajaran diarahkan oleh guru dan berorientasi pada teks, (8) promosi tergantung pada penilaian guru, (9) kurikulum berpusat pada subjek pendidik, (10) bahan ajar yang paling umum tertera dalam kurikulum adalah buku-buku teks. ${ }^{11}$

Lebih lanjut menurut Vernon Smith, pendidikan tradisional didasarkan pada beberapa asumsi yang umumnya diterima orang meski tidak disertai bukti keandalan atau kesahihan. Umpamanya: 1). ada suatu kumpulan pengetahuan dan keterampilan penting tertentu yang musti dipelajari anak-anak; 2). tempat terbaik bagi sebagian besar anak untuk mempelajari unsur-unsur ini adalah sekolah formal, dan 3). cara terbaik supaya anak-anak bisa belajar adalah mengelompokkan mereka dalam kelas-

\footnotetext{
${ }^{10}$ M.Dimyati Machmud, Psikologi Pendidikan, Yogyakarta, BPFE, 1990. 3.

11 Paulo Freire,dkk., Menggugat Pendidikan Fundamental Konservatif Liberal Anarkis, Terj., Omi Intan Naomi, Pustaka Pelajar, 1999.
} 
kelas yang ditetapkan berdasarkan usia mereka. ${ }^{12}$

Ciri yang dikemukan Vernon Smith ini juga dialami oleh pendidikan Islam di Indonesia sampai dekade ini. Misalnya : Sebagian Pesantren, Madrasah, dan lembaga-lembaga pendidikan Islam yang lain masih menganut sistem lama, kurikulum ditetapkan merupakan paket yang harus diselesaikan, kurikulum dibuat tanpa atau sedikit sekali memperhatikan konteks atau relevansi dengan kondisi sosial masyarakat bahkan sedikit

sekali memperhatika dan mengantisipasi perubahan zaman, sistem pembelajaran berorientasi atau berpusat pada guru. Paradigma pendidikan tradisional bukan merupakan sesuatu yang salah atau kurang baik, tetapi model pendidikan yang berkembang dan sesuai dengan zamannya, yang tentu juga memiliki kelebihan dan kelemahan dalam memberdayakan manusia, apabila dipandang dari era modern ini. Konsep pendidikan modern (konsep baru), yaitu ; pendidikan menyentuh setiap aspek kehidupan peserta didik, pendidikan merupakan proses belajar yang terus menerus, pendidikan dipengaruhi oleh kondisi-kondisi dan pengalaman, baik di dalam maupun di luar situasi sekolah, pendidikan dipersyarati oleh kemampuan dan minat peserta didik, juga tepat tidaknya situasi belajar dan efektif tidaknya cara mengajar. ${ }^{13}$ Pendidikan pada masyarakat modern atau masyarakat yang tengah bergerak ke arah modern (modernizing), seperti masyarakat Indonesia, pada dasarnya berfungsi memberikan kaitan antara anak didik dengan lingkungan sosial kulturalnya yang terus berubah dengan cepat.

Shipman yang dikutip Azyumardi Azra bahwa, fungsi pokok pendidikan dalam masyarakat modern yang tengah membangun terdiri dari tiga bagian : (1) sosialisasi, (2) pembelajaran (schooling), dan (3) pendidikan (education). Pertama, sebagai lembaga sosialisasi, pendidikan adalah wahana bagi integrasi anak didik ke dalam nilai-nilai kelompok atau nasional yang dominan. Kedua, pembelajaran (schooling) mempersiapkan mereka untuk mencapai dan menduduki posisi sosial- ekonomi tertentu dan, karena itu, pembelajaran harus dapat membekalai peserta didik dengan kualifikasikualifikasi pekerjaan dan profesi yang akan membuat mereka mampu memainkan peran sosial-ekonomis dalam masyarakat. Ketiga, pendidikan merupakan "education" untuk menciptakan kelompok elit yang pada gilirannya akan memberikan sumbangan besar bagi kelanjutan program

12 Paulo Freire,dkk., Menggugat Pendidikan Fundamental Konservatif Liberal Anarkis, Terj., Omi Intan Naomi, Pustaka Pelajar, 1999. 165

${ }^{13}$ M. Dimyati Machmud, Psikologi Pendidikan, Yogyakarta, BPFE, 1990.3 
pembangunan". ${ }^{14}$

\section{Pendidikan Islami yang Bagaimana?}

Perubahan yang terjadi dalam kehidupan masyarakat baik sosial maupun kultural, secara makro persoalan yang dihadapi pendidikan Islam adalah bagaimana pendidikan Islam mampu menghadirkan disain atau konstruksi wacana pendidikan Islam yang relevan dengan perubahan masyarakat. Kemudian disain wacana pendidikan Islam tersebut dapat dan mampu ditranspormasikan atau diproses secara sistematis dalam masyarakat. Persoalan pertama ini lebih bersifat filosofis, yang kedua lebih bersifat metodologis. Pendidikan Islam perlu menghadirkan suatu konstruksi wacana pada dataran filosofis, wacana metodologis, dan juga cara menyampaikan atau mengkomunikasikannya.

Dalam menghadapi peradaban modern, yang perlu diselesaikan adalah persoalan-persoalan umum internal pendidikan Islam yaitu (1) persoalan dikotomik, (2) tujuan dan fungsi lembaga pendidikan Islam, (3) persoalan kurikulum atau materi. Ketiga persoalan ini saling interdependensi antara satu dengan lainnya.

Pertama, Persolan dikotomik pendidikan Islam, yang merupakan persoalan lama yang belum terselesaikan sampai sekarang. Pendidikan Islam harus menuju pada integritas antara ilmu agama dan ilmu umum untuk tidak melahirkan jurang pemisah antara ilmu agama dan ilmu bukan agama. Karena, dalam pandangan seorang Muslim, ilmu pengetahuan adalah satu yaitu yang berasal dari Allah SWT. ${ }^{15}$ Mengenai persoalam dikotomi, tawaran Fazlur Rahman, salah satu pendekatannya adalah dengan menerima pendidikan sekuler modern sebagaimana telah berkembang secara umumnya di dunia Barat dan mencoba untuk "mengislamkan"nya - yakni mengisinya dengan konsep-konsep kunci tertentu dari Islam. Lebih lanjut Fazlur Rahman, mengatakan persoalannya adalah bagaimana melakukan modernisasi pendidikan Islam, yakni membuatnya mampu untuk produktivitas intelektual Islam yang kreatif dalam semua bidang usaha intelektual bersama-sama dengan keterkaiatan yang serius kepada Islam,

14 Azyumardi Azra, dalam Marwan Saridjo, Bunga Rampai Pendidikan Agama Islam, Amissco, Jakarta, 1996. Comference Book, London, 1978. 3.

15 Soroyo, Antisipasi Pendidikan Islam dan Perubahan Sosial Menjangkau Tahun 2000, dalam Buku : Pendidikan Islam di Indonesia antara Cita dan Fakta, Editor : Muslih Usa, Tiara Wacana, Yogya, 1991. 45. 
Syafi'i Ma'arif mengatakan bila konsep dualisme dikotomik berhasil ditumbangkan, maka dalam jangka panjang sistem pendidikan Islam juga akan berubah secara keseluruhan, mulai dari tingkat dasar sampai ke perguruan tinggi. Untuk kasus Indonesia, IAIN misalnya akan lebur secara integratif dengan perguruan tinggi-perguruan tinggi negeri lainnya. ${ }^{16}$ Peleburan bukan dalam bentuk satu atap saja, tetapi lebur berdasarkan rumusan filosofis.

Kedua, perlu pemikiran kembali tujuan dan fungsi lembaga-lembaga pendidikan Islam yang ada. Memang diakui bahwa penyesuaian lembagalembaga pendidikan akhir-akhir ini cukup mengemberikan, artinya lembagalembaga pendidikan memenuhi keinginan untuk menjadikan lembagalembaga tersebut sebagai tempat untuk mempelajari ilmu umum dan ilmu agama serta keterampilan. ${ }^{17}$ Tetapi pada kenyataannya penyesuaian tersebut lebih merupakan peniruan dengan pola tambal sulam atau dengan kata lain mengadopsi model yang dilakukan oleh lembaga-lembaga pendidikan umum, artinya ada perasaan harga diri bahwa apa yang bisa dilakukan oleh lembagalembaga pendidikan umum dapat juga dilakukan oleh lembaga-lembaga pendidikan agama, sehingga akibatnya beban kurikulum yang terlalu banyak dan cukup berat dan terjadi tumpang tindih. Sebenarnya lembaga-lembaga pendidikan Islam harus memilih satu di antara dua fungsi, apakah mendisain model pendidikan umum Islami yang handal dan mampu bersaing dengan lembaga-lembaga pendidikan yang lain, atau mengkhususkan pada disain pendidikan keagamaan yang berkualitas, mampu bersaing, dan mampu mempersiapkan mujtahid-mujtahid yang berkualitas. Ketiga, persoalan kurikulum atau materi Pendidikan Islam, meteri pendidikan Islam "terlalu dominasi masalah-maslah yang bersifat normatif, ritual dan eskatologis. Materi disampaikan dengan semangat ortodoksi kegamaan, suatu cara dimana peserta didik dipaksa tunduk pada suatu "meta narasi" yang ada, tanpa diberi peluang untuk melakukan telaah secara kritis. Pendidikan Islam tidak fungsional dalam kehidupan sehari-hari, kecuali hanya sedikit aktivitas verbal dan formal untuk menghabiskan materi atau kurikulum yang telah diprogramkan dengan batas waktu yang telah ditentukan.

Mencermati persoalan yang dikemukakan di atas, maka perlu menyelesaikan persoalan internal yang dihadapi pendidikan Islam secara

${ }^{16}$ Ahmad Syafi'i Ma'arif, Pemikiran tentang .. 7.

${ }^{17}$ Anwar Jasin, Keranka Dasar Pembaharuan Pendidikan Islam : Tinjauan Filosofis, 1985.15 
mendasar dan tuntas. Sebab pendidikan sekarang ini juga dihadapkan pada persoalan-persoalan yang cukup kompleks, yakni bagaimana pendidikan mampu mempersiapkan manusia yang berkualitas, bermoral tinggi dalam menghadapi perubahan masyarakat yang begitu cepat, sehingga produk pendidikan Islam tidak hanya melayani dunia modern, tetapi mempunyai pasar baru atau mampu bersaing secara kompettif dan proaktif dalam dunia masyarakat modern. Pertanyaannya, disain pendidikan Islami yang bagaimana? Yang mampu menjawab tantangan perubahan ini, antara lain: Pertama, lembaga-lembaga pendidikan Islam perlu mendisain ulang fungsi pendidikannya, dengan memilih apakah (1) model pendidikan yang mengkhususkan diri pada pendidikan keagamaan saja untuk mempersiapkan dan melahirkan ulama-ulama dan mujtahid-mujtahid tangguh dalam bidangnya dan mampu menjawab persoalan-persoalan aktual atau kontemporer sesuai dengan perubahan zaman, (2) model pendidikan umum Islami, kurikulumnya integratif antara materi-materi pendidikan umum dan agama, untuk mempersiapkan intelektual Islam yang berfikir secara komprehensif, (3) model pendidikan sekuler modern dan mengisinya dengan konsep-konsep Islam, (4) atau menolak produk pendidikan barat, berarti harus mendisain model pendidikan yang betul-betul sesuai dengan konsep dasar Islam dan sesuai dengan lingkungan sosial-budaya Indonesia, (5) pendidikan agama tidak dilaksanakan di sekolah-sekolah tetapi dilaksanakan di luar sekolah, artinya pendidikan agama dilaksanakan di rumah atau lingkungan keluarga dan lingkungan masyarakat berupa kursur-kursus, dan sebagainya. Kedua disain "pendidikan harus diarahkan pada dua dimensi, yakni : (1) dimensi dialektika (horisontal), pendidikan hendaknya dapat mengembangkan pemahaman tentang kehidupan manusia dalam hubungannya dengan alam atau lingkungan sosialnya. Manusia harus mampu mengatasi tantangan dan kendala dunia sekitarnya melalui pengembangan Iptek, dan (2) dimensi ketunduhan vertikal, pendidikan selain menjadi alat untuk memantapkan, memelihara sumber daya alami, juga menjembatani dalam memahamai fenomena dan misteri kehidupan yang abadi dengan maha pencipta. Berati pendidikan harus disertai dengan pendekatan hati. ${ }^{18}$ Ketiga, sepuluh paradigma yang ditawarkan oleh Prof. Djohar, dapat digunakan untuk membangun paradiga baru pendidikan Islam, sebagai berikut : Satu, pendidikan adalah proses pembebasan. Dua, pendidikan sebagai proses

\footnotetext{
${ }^{18}$ M. Irsyad Sudiro, Pendidikan Agama.., 2.
} 
pencerdasan. Tiga, pendidikan menjunjung tinggi hak-hak anak. Empat, pendidikan menghasilkan tindakan perdamaian. Lima, pendidikan adalah proses pemberdayaan potensi manusia. Enam, pendidikan menjadikan anak berwawasan integratif. Tujuh, pendidikan wahana membangun watak persatuan. Delapan, pendidikan menghasilkan manusia demokratik. Sembilan, pendidikan menghasilkan manusia yang peduli terhadap lingkungan. Sepuluh, sekolah bukan satu-satunya instrumen pendidikan. ${ }^{19}$

Tiga hal yang dikemukakan di atas merupakan tawaran desain pendidikan Islam yang perlu diupayakan untuk membangun paradigma pendidikan Islam dalam menghadapi perkembangan perubahan zaman modern dan memasuki era milenium ketiga. Karena, "kecenderungan perkembangan semacam dalam mengantisipasi perubahan zaman merupakan hal yang wajar-wajar saja. Sebab kondisi masyarakat sekarang ini lebih bersifat praktis-pragmatis dalam hal aspirasi dan harapan terhadap pendidikan", ${ }^{20}$ sehingga tidak statis atau hanya berjalan di tempat dalam menatap persoalan-persoalan yang dihadapi pada era masyarakat modern dan post masyarakat modern. Untuk itu, Pendidikan dalam masyarakat modern, pada dasarnya berfungsi untuk memberikan kaitan antara anak didik dengan lingkungan sosiokulturalnya yang terus berubah dengan cepat, dan pada saat yang sama, pendidikan secara sadar juga digunakan sebagai instrumen untuk perubahan dalam sistem politik, ekonomi secara keseluruhan. Pendidikan sekarang ini seperti dikatakan oleh Ace Suryadi dan H.A.R. Tilar (1993), ${ }^{21}$ tidak lagi dipandang sebagai bentuk perubahan kebutuhan yang bersifat konsumtif dalam pengertian pemuasan secara langsung atas kebutuhan dan keinginan yang bersifat sementara. Tapi, merupakan suatu bentuk investasi sumber daya manusia (human investment) yang merupakan tujuan utama; pertama, pendidikan dapat membantu meningkatkan ketrampilan dan pengetahuan untuk bekerja lebih produktif sehingga dapat meningkatkan penghasilan kerja lulusan pendidikan di masa mendatang. Kedua, pendidikan diharapkan memberikan pengaruh terhadap pemerataan kesempatan memperoleh pendidikan (equality of education opportunity) (A.Malik Fadjar, $1995: 1)$.

19 Djohar, Omong Kosong, Tanpa Mengubah UU No. 2/89, Koran Harian "Kedaulatan Rakyat", Tangga, 4 Mei 199.

${ }^{20}$ S.R. Parker, et.al, Sosiologi Industri, Rineka Cipta, Jakarta, 1990.

${ }^{21}$ H.A.R. Tilar, Beberapa Agenda Reformasi Pendidikan Nasional Dalam Perspektif Abad 21, Tera Indonesia, Magelang, Cet. I, 1998. 
Selain itu dalam menghadapi era milenium ketiga ini nampaknya pendidikan Islam harus menyiapkan sumber daya manusia yang lebih handal yang memiliki kompotensi untuk hidup bersama dalam era global. Menurut Djamaluddin Ancok, "salah satu pergeseran paradigma adalah paradigma di dalam melihat apakah kondisi kehidupan di masa depan relatif stabil dan bisa diramalkan (predictability). Pada milenium kedua orang selalu berpikir bahwa segala sesuatu bersifat stabil dan bisa diprediksi. Tetapi, pada milenium ketiga semakin sulit untuk melihat adanya stabilitas tersebut. Apa yang terjadi di depan semakin sulit untuk diprediksi karena perubahan menjadi tidak terpolakan dan tidak lagi bersifat linier". ${ }^{22}$ Maka, pendidikan Islam sekarang ini disainnya tidak lagi bersifat linier tetapi harus didisan bersifat lateral dalam menghadapi perubahan zaman yang begitu cepat dan tidak terpolakan. Untuk itu, lebih lanjut Djamaluddin Ancok yang mengutip Hartanto : 1997: Hartanto, Raka \& Hendroyuwono, 1998, mengatakan bahwa pendidikan (termasuk pendidikan Islam) harus mempersiapkan ada empat kapital yang diperlukan untuk memasuki milenium ketiga, yakni kapital intelektual, kapital sosial, kapital lembut, dan kapital spritual. Tantangan ini tidak muda untuk penyelesaiannya, tidak seperti membalik telapak tangan. Untuk itu, pendidikan Islam sangat perlu mengadakan perubahan atau mendesain ulang konsep, kurikulum dan materi, fungsi dan tujuan lembagalembaga, proses, agar dapat meneuhi tuntatan perubahan yang semakin cepat.

\section{Kesimpulan}

Dari pembahasan di atas dapat disimpulkan bahwa : (1) Dalam menghadapi perubahan masyarakat modern, secara internal pendidikan Islam harus menyelesaikan persoalan dikotomi, tujuan dan fungsi lembaga pendidikan Islam, dan persolalan kurikulum atau materi yang sampai sekarang ini belum terselesaikan. (2) Lembaga- lembaga pendidikan Islam perlu mendisain ulang fungsi pendidikan, dengan memilih model pendidikan yang relevan dengan perubahan zaman dan kebutuhan masyarakat. (3) Pendidikan Islam didisain untuk dapat membantu meningkatkan ketrampilan dan pengetahuan untuk bekerja lebih produktif sehingga dapat meningkatan kerja lulusan pendidikan di masa datang. Selain itu perlu disain pendidikan Islam yang tidak hanya bersifat linier saja, tetapi harus bersifat lateral dalam

${ }^{22}$ Djamaluddin Ancok, Membangun Kompotensi Manusia dalam Milenium Ke Tiga, Psikologika, Jurnal Pemikiran dan Penelitian Psikologi, Nomor : 6 Tahun III, UII, 1998. 5 
menghadapi perubahan zaman yang begitu cepat. (4) Pendidikan Islam harus mengembangkan kualitas pendidikannya agar memenuhi kebutuhankebutuhan masyarakat yang selalu berubah-berubah.Lembaga-lembaga pendidikan Islami harus dapat menyiapkan sumber insani yang lebih handal dan memiliki kompotensi untuk hidup bersama dalam ikatan masyarakat modern. 


\section{DAFTAR PUSTAKA}

Achwan, Roehan. "Prinsip-prinsip Pendidikan Islam Versi Mursi", Jurnal Pendidikan Islam, Volume 1, IAIN Sunan Kalija, Yogyakarta, 1991.

Ancok, Djamaluddin. "Membangun Kompotensi Manusia dalam Milenium Ke Tiga," Psikologika, Jurnal Pemikiran dan Penelitian Psikologi, Nomor : 6 Tahun III, UII, 1998.

Azra, Azyumardi, dalam Marwan Saridjo, Bunga Rampai Pendidikan Agama Islam, Amissco, Jakarta, 1996. Comference Book, London, 1978.

an-Nahlawi, Abdurrahman. Ushulut Tarbiyah Islamiyah wa Asalabih fi Baiti wa Madrasati wal Mujtama', Dar al-Fikr al-Mu'asyr, Beirut-Libanon., Terj. Shihabuddin, Pendidikan Islam di Rumah Sekolah dan Masyarakat, Gema Insani Press, Jakarta, 1995.

Djohar, Omong Kosong, Tanpa Mengubah UU No. 2/89, Koran Harian "Kedaulatan Rakyat", Tangga, 4 Mei 199.

Erich Fromm, The Revolution of Hope : Toward a Humanized Technology, New York : Harper \& Raw, 1968, p. 5.,dalam Syafi'i Ma'arif, Pengembangan Pendidikan Tinggi Post Graduate Studi Islam Melalui Paradigma Baru Yang Lebih Efektif, 1997.

Fadjar, A. Malik. Menyiasati Kebutuhan Masyarakat Modern Terhadap Pendidikan Agama Luar Sekolah, Seminar dan Lokakarya Pengembangan Pendidikan Islam Menyongsong Abad 21, IAIN, Cirebon, tanggal, 31 Agustus s/d 1 September 1995.

Freire, Paulo. dkk., Menggugat Pendidikan Fundamental Konservatif Liberal Anarkis, Terj., Omi Intan Naomi, Pustaka Pelajar, 1999H.A.R. Tilar, Beberapa Agenda Reformasi Pendidikan Nasional Dalam Perspektif Abad 21, Tera Indonesia, Magelang, Cet. I, 1998.

Husaian, Syed Sajjad dan Ashraf, Syed Ali. Crisis Muslim Educatio"., Terj. Rahmani Astuti, Krisis Pendidikan Islam, Risalah, Bandung, 1986.

Jasin, Anwar. Keranka Dasar Pembaharuan Pendidikan Islam : Tinjauan Filosofis, 1985.

Machmud, M.Dimyati. Psikologi Pendidikan, Yogyakarta, BPFE, 1990. 
Ma'arif, Ahmad Syafi'i. Pemikiran tentang Pembaharuan Pendidikan Islam di Indonesia, Dalam Pendidikan Islam di Indonesia antara Cita dan Fakta, Editor : Muslih Usa, Tiara Wacana, Yogyakarta, 1991.

------- Pengembangan Pendidikan Tinggi Post Graduate Studi Islam Melalui Paradigma Baru yang Lebih Efektif, Makalah Seminar, 1997.

Rahman, Fazlur. Islam and Modernity, Transformation of an Intellectual Tradition, The University of Chicago, Chicagi, 1982., terj. Ahsin Mohammad, Pustaka, 1985.

S.R. Parker, et.al, Sosiologi Industri, Rineka Cipta, Jakarta, 1990.

Soroyo, Antisipasi Pendidikan Islam dan Perubahan Sosial Menjangkau Tahun 2000, dalam Buku : Pendidikan Islam di Indonesia antara Cita dan Fakta, Editor : Muslih Usa, Tiara Wacana, Yogya, 1991.

Sudiro, M. Irsyad. Pendidikan Agama dalam Masyarakat Modern, Seminar dan Lokakarya Nasional Revitalisasi Pendidikan Agama Luar Sekolah dalam Masyarakat Modern, Cirebon, tanggal, 30-31 Agusrus 1995. 